\title{
Effect of Holding Solutions on Biochemical and Microbial Observations in Extending the Vase Life of Cut Carnation cv. Kiro
}

\author{
P. Pranuthi, T. Suseela, D.V. Swami*, D.R. Salomi Suneetha and V. Sudha Vani \\ Department of Floriculture and Landscape Architecture, Dr. Y.S.R. Horticultural University, \\ Venkataramannagudem, West Godavari dist. (Andhra Pradesh), India \\ *Corresponding author
}

\section{A B S T R A C T}

Keywords

Carnation, Holding

solution, Chlorophyll

content, Microbial count

and vase life

Article Info

Accepted:

10 July 2018

Available Online:

10 August 2018
An experiment was carried out to study the effect of different holding solution combinations on vase life of cut carnation cv. Kiro. The flowers were kept under common holding solution (sucrose $4 \%+8$-HQS $200 \mathrm{ppm}$ ) along with $\mathrm{GA}_{3}$ at 25 ppm recorded the highest chlorophyll content of leaf (87.48 SPAD unit) on $2^{\text {nd }}$ day and gradually decreased through vase life extends, whereas significantly the highest chlorophyll content of calyx (46.86 SPAD unit) extended through the vase life period resulting in reduced microbial count $\left(1.00 \times 10^{-5} \mathrm{cfu} / \mathrm{ml}\right)$ initially and $\left(85.10 \times 10^{-5} \mathrm{cfu} / \mathrm{ml}\right)$ final microbial count thereby extending maximum vase life (20.32 days) which has been extended the vase life period of carnation flower cv. Kiro.

\section{Introduction}

Carnation (Dianthus caryophyllus L.) is an important cut flower in the world. Carnation is a climatric flower that is highly sensitive to ethylene (Pun et al., 1999). Due to high perishability, cut flowers are vulnerable to large post-harvest losses upto 50 per cent of the farm value (Singh et al., 2007).

Carnations are more susceptible to mechanical and physical damages and microbial infections by diseases and pests during and after harvest. Floral preservatives affect the quality of cut flowers by extending the vase life, increasing flower size and maintaining the colour of leaves and petals. The vase life of cut flowers and foliage is often shortened by vascular occlusions that constrict vase solutions supply, reduction in stem conductivity is typically caused by blockage of cut stem ends and xylem conduits by microbes, physiological plugging and water columns in xylem vessels by cavitations and air emboli. Cut flower and foliage longevity can be greatly affected by chemical composition of the vase solution. A broad range of biocides has been suggested to prevent the proliferation of microorganisms in vase solutions. However, their assumed antimicrobial action may be confounded by their other physicochemical effects (Edrisi et al., 2012). Water relations plays a critical role in the post-harvest life of cut flowers, water imbalance within the cut flower resulting in 
wilting, one of the major causes for termination of vase life (Halevy and Mayak, 1981).

\section{Materials and Methods}

The experiment was held in laboratory of Floriculture and Landscape Architecture, College of Horticulture, Dr. Y.S.R. Horticultural University, Venkataramannagudem, West Godavari dist (A.P), during year 2017-18. Experiment laid out in completely randomised design. Sucrose $4 \%+$ 8-HQS 200 ppm was used as common holding solution. There are 11 treatments, $\mathrm{T}_{1}$ : holding solution $+\mathrm{GA}_{3} 25 \mathrm{ppm}, \mathrm{T}_{2}$ : holding solution + $\mathrm{GA}_{3} 50 \mathrm{ppm}, \mathrm{T}_{3}$ : holding solution $+\mathrm{BA} 25$ ppm, $\mathrm{T}_{4}$ : holding solution + BA $50 \mathrm{ppm}, \mathrm{T}_{5}$ : holding solution $+\mathrm{Al}_{2}\left(\mathrm{SO}_{4}\right)_{3} 150 \mathrm{ppm}, \mathrm{T}_{6}$ : holding solution $+\mathrm{Al}_{2}\left(\mathrm{SO}_{4}\right)_{3} 300 \mathrm{ppm}, \mathrm{T}_{7}$ : holding solution + STS $0.25 \mathrm{mM}, \mathrm{T}_{8}$ : holding solution + STS $0.50 \mathrm{mM}, \mathrm{T}_{9}$ : holding solution + Salicylic acid $25 \mathrm{ppm}, \mathrm{T}_{10}$ : holding solution + Salicylic acid $50 \mathrm{ppm}, \mathrm{T}_{11}$ : control (only holding solution). All the treatments are replicated thrice at $25 \pm 2^{\circ} \mathrm{C}$ ambient room temperature, 45-55 per cent relative humidity $\mathrm{RH}$ and $40 \mathrm{~W}$ cool white florescent tubes to maintain 12 hours photoperiod. In each conical flask, six flowers were placed in each $500 \mathrm{ml}$ conical flasks $300 \mathrm{ml}$ of holding solution. Observations were recorded changes on chlorophyll content of leaf, chlorophyll content of calyx, microbial count and vase life.

\section{Results and Discussion}

The data indicated that flowers kept in holding solution (sucrose 4\% + 8-HQS 200 ppm) along with $\mathrm{GA}_{3}$ at $25 \mathrm{ppm}$ recorded the highest total chlorophyll content of leaf (87.48 SPAD unit) on $2^{\text {nd }}$ day and gradually decreased towards $10^{\text {th }}$ day (83.62 SPAD unit) of vase life period which was on par with flowers kept in holding solution along with $\mathrm{GA}_{3}$ at $50 \mathrm{ppm}$, followed by flowers kept in holding solution along with BA at $25 \mathrm{ppm}$ (85.12 SPAD unit) on $2^{\text {nd }}$ day to $10^{\text {th }}$ day (80.09 SPAD unit) of vase life period. This might be due to the synergistic effect of HQS and sucrose individually helps in preserving the leaves in good condition by lowering the per cent of wilting and inhibiting the chlorophyll and carbohydrate degradation. $\mathrm{GA}_{3}$ involves in hydrolysis of polysaccharides and possibly delaying chlorophyll degradation or structural role in chloroplast photosynthesis. As a result, the vase life could be increased. The chlorophyll content was intensified when the flower dry matter content was higher and then it has faded due to depletion and damage of the chloroplasts in the calyx and leaf at advanced senescence, decreased chlorophyll content in leaves with increased storage period. Similar results were obtained by Tarannum et al., (2016) in carnation, Mohan et al., (2016) in cut rose, Jeevitha (2016) in bird-of paradise, Davood et al., (2015) and Madhuri et al., (2016) in carnation.

The total chlorophyll content of calyx differed significantly among all the treatments and the highest chlorophyll content of calyx (46.86 SPAD unit) on $2^{\text {nd }}$ day to $10^{\text {th }}$ day $(44.12$ SPAD unit) of vase life period was obtained by flowers kept in holding solution (sucrose $4 \%+8$-HQS 200 ppm) along with $\mathrm{GA}_{3}$ at 25 ppm, followed by flowers kept in holding solution along with $\mathrm{GA}_{3}$ at $50 \mathrm{ppm}(43.78$ SPAD unit) on $2^{\text {nd }}$ day to $10^{\text {th }}$ day (42.56 SPAD unit) of vase life period. This might be due the chlorophyll content of calyx increased initially and then decreased gradually, this might be due to increased chlorophyllase activity during initial days because of better water relations in flower stalk. These results were in accordance with Genkov et al., (1997). Similar results were obtained by Abdul and Asrar (2012) in Antirrhinum, Madhuri et al., (2016) in carnation (Table 1 and 2). 
Table.1 Effect of different holding solutions on chlorophyll content on leaf (SPAD unit) and chlorophyll content of calyx (SPAD unit) during vase life of cut carnation cv. Kiro

\begin{tabular}{|c|c|c|c|c|c|c|c|c|c|c|}
\hline \multirow[t]{3}{*}{ Treatments } & \multicolumn{10}{|c|}{ Time period (days) } \\
\hline & \multicolumn{5}{|c|}{ Chlorophyll content of leaf (SPAD unit) } & \multicolumn{5}{|c|}{ Chlorophyll content of calyx (SPAD unit) } \\
\hline & 2 & 4 & 6 & 8 & 10 & 2 & 4 & 6 & 8 & 10 \\
\hline $\mathbf{T}_{1}$-Holding solution + GA $\mathbf{A}_{3} @$ 25ppm & 87.48 & 89.75 & 87.5 & 85.49 & 83.62 & 46.86 & 48.23 & 46.85 & 45.24 & 44.12 \\
\hline $\mathbf{T}_{2}$-Holding solution + GA 3 @ 50ppm & 86.12 & 87.90 & 85.78 & 84.02 & 81.70 & 43.78 & 46.74 & 44.50 & 43.56 & 42.56 \\
\hline T3:-Holding solution + BA @ 25ppm & 85.12 & 87.01 & 86.05 & 82.63 & 80.09 & 43.10 & 45.30 & 42.76 & 40.38 & 37.42 \\
\hline T4-Holding solution + BA @ 50ppm & 83.56 & 85.42 & 83.91 & 81.14 & 78.40 & 40.84 & 42.55 & 38.62 & 37.42 & 36.45 \\
\hline $\begin{array}{l}\mathrm{T}_{5} \text { - Holding solution }+\mathrm{Al}_{2}\left(\mathrm{SO}_{4}\right)_{3} @ \\
150 \mathrm{ppm}\end{array}$ & 82.50 & 84.53 & 83.14 & 80.08 & 76.83 & 39.17 & 41.00 & 37.98 & 36.63 & 35.91 \\
\hline $\begin{array}{l}\mathrm{T}_{6} \text { - Holding solution + } \mathrm{Al}_{2}\left(\mathrm{SO}_{4}\right)_{3} @ \\
\text { 300ppm }\end{array}$ & 83.04 & 85.00 & 84.13 & 80.79 & 78.01 & 40.36 & 41.56 & 38.45 & 36.89 & 36.12 \\
\hline T 7 - Holding solution + STS @ 0.25 mM & 81.92 & 82.19 & 81.43 & 78.58 & 72.85 & 38.67 & 40.19 & 36.48 & 34.17 & 33.65 \\
\hline T/8- Holding solution + STS @ 0.50 mM & 82.17 & 83.78 & 82.9 & 79.90 & 75.74 & 38.93 & 40.85 & 37.65 & 36.32 & 35.46 \\
\hline $\begin{array}{l}\text { T9:Holding solution + Salicylic acid @ } \\
\text { 25ppm }\end{array}$ & 80.75 & 81.54 & 80.64 & 76.56 & 70.32 & 36.94 & 37.15 & 35.17 & 34.45 & 33.24 \\
\hline $\begin{array}{l}\text { T10: Holding solution + Salicylic acid @ } \\
\text { 50ppm }\end{array}$ & 81.64 & 82.01 & 81.23 & 78.10 & 71.50 & 37.42 & 38.45 & 35.91 & 35.26 & 34.44 \\
\hline $\mathrm{T}_{11}$ : Control (only holding solution) & 79.80 & 80.18 & 79.47 & 75.60 & - & 36.09 & 36.97 & 30.56 & 30.07 & - \\
\hline Mean & 83.13 & 84.48 & 83.27 & 80.27 & 69.95 & 40.10 & 41.72 & 38.63 & 37.30 & 33.57 \\
\hline SE d & 1.816 & 1.239 & 1.731 & 1.823 & 1.219 & 0.88 & 0.547 & 0.874 & 0.820 & 0.964 \\
\hline C.D at 5\% & 3.778 & 2.585 & 3.613 & 3.804 & 2.543 & 1.837 & 1.143 & 1.825 & 1.712 & 2.011 \\
\hline
\end{tabular}


Table.2 Effect of different holding solutions on microbial count (cfu/ml) and vase life (days) during vase life of cut carnation cv. Kiro

\begin{tabular}{|c|c|c|c|}
\hline \multirow[t]{2}{*}{ Treatments } & \multicolumn{2}{|c|}{ Microbial count (cfu/ml) $\left(10^{5}\right.$ dilutions $)$} & \multirow{2}{*}{$\begin{array}{c}\text { Vase life (days) } \\
\text { days }\end{array}$} \\
\hline & Initial & Final & \\
\hline $\mathrm{T}_{1}$-Holding solution + GA 3 @ 25ppm & 1.00 & 85.10 & 20.32 \\
\hline 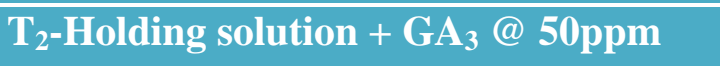 & 1.60 & 87.22 & 19.60 \\
\hline T3:-Holding solution + BA @ 25ppm & 3.02 & 95.30 & 17.92 \\
\hline T4-Holding solution + BA @ 50ppm & 2.60 & 96.14 & 18.32 \\
\hline $\begin{array}{l}\mathrm{T}_{5^{-}} \text {Holding solution }+\mathrm{Al}_{2}\left(\mathrm{SO}_{4}\right)_{3} @ \\
150 \mathrm{ppm}\end{array}$ & 3.50 & 99.14 & 15.60 \\
\hline $\begin{array}{l}\mathrm{T}_{6} \text { - Holding solution + } \mathrm{Al}_{2}\left(\mathrm{SO}_{4}\right)_{3} @ \\
\text { 300ppm }\end{array}$ & 3.16 & 98.02 & 16.78 \\
\hline T & 4.30 & 109.80 & 13.45 \\
\hline T/8 Holding solution + STS @ 0.50 Mm & 3.80 & 100.08 & 14.35 \\
\hline $\begin{array}{l}\text { T9:Holding solution + Salicylic acid @ } \\
\text { 25ppm }\end{array}$ & 4.98 & 121.00 & 11.71 \\
\hline $\begin{array}{l}\mathrm{T}_{10}: \text { Holding solution + Salicylic acid @ } \\
50 \mathrm{ppm}\end{array}$ & 4.80 & 117.06 & 12.00 \\
\hline $\mathrm{T}_{11}$ : Control (only holding solution) & 5.90 & 130.00 & 9.50 \\
\hline Mean & 3.51 & 10.3 .53 & 15.39 \\
\hline SE d & 0.068 & 2.066 & 0.356 \\
\hline C.D at 5\% & 0.143 & 4.186 & 0.744 \\
\hline Significance & $*$ & $*$ & $*$ \\
\hline
\end{tabular}


A perusal of data indicates that flowers kept in holding solution along with $\mathrm{GA}_{3}$ at $25 \mathrm{ppm}$ $\left(\mathrm{T}_{1}\right)$ recorded the lowest microbial growth $\left(1.00 \times 10^{-5} \mathrm{cfu} / \mathrm{ml}\right)$ during initial count as well as final count $\left(85.10 \times 10^{-5} \mathrm{cfu} / \mathrm{ml}\right)$ which was followed by flowers kept in holding solution along with $\mathrm{GA}_{3}$ at $50 \mathrm{ppm}\left(\mathrm{T}_{2}\right)$ during initial count $\left(4.48 \times 10^{-5} \mathrm{cfu} / \mathrm{ml}\right)$ and final count $\left(98.76 \times 10^{-5} \mathrm{cfu} / \mathrm{ml}\right)$. The highest microbial count during initial count $\left(5.90 \times 10^{-5} \mathrm{cfu} / \mathrm{ml}\right)$ and final count $\left(130.00 \times 10^{-5} \mathrm{cfu} / \mathrm{ml}\right)$ was observed with flowers kept in control treatment $\left(\mathrm{T}_{11}\right)$ only holding solution. This could be due to sucrose served as a source of energy for microbes, which might have helped its growth to increase their population in vase solution. Similar results were observed by Vijayabhaskar (2002) that maximum microbial count was recorded with higher concentrations of sucrose in the vase solution of cut rose cv. First red. Reduced microbial growth was due to their biocide effect in vase solution (Loubaud and Van Doorn, 2004).

The vase life period of cut carnation differed significantly among the treatments. All the treatments have significantly improved vase life over control (only holding solution) $\left(\mathrm{T}_{11}\right)$. Among the different treatments, flowers kept in holding solution along with $\mathrm{GA}_{3} @ 25$ ppm $\left(\mathrm{T}_{1}\right)$ recorded significantly the longest vase life (20.32 days) which was on par with flowers kept in holding solution along with $\mathrm{GA}_{3} @ 50$ ppm $\left(\mathrm{T}_{2}\right)$ (19.60 days), followed by flowers kept in holding solution along with BA @ 25 ppm (18.32 days). Among all the treatments the lowest vase life (9.50 days) was observed with flowers kept in control (only holding solution) $\left(\mathrm{T}_{11}\right)$. The vase life period ranged from 9.50 to 20.32 days. The data indicated that flowers kept in holding solution (sucrose 4\% + 8-HQS @ 200 ppm) along with $\mathrm{GA}_{3} @ 25 \mathrm{ppm}\left(\mathrm{T}_{1}\right)$ recorded significantly the longest vase life. This might be due to $\mathrm{GA}_{3}$ with sucrose further facilitated the better intake of water and accumulation of total soluble sugars in petal cells probably by enhancing the osmotic driving force for solution uptake by making the cell's water potential more negative which leads to have longer vase life. 8-HQS itself reduced the transpiration and improved water balance due to stomatal closure might have added to keep the flowers fresh for a longer duration. Similar results were also recorded by in Elhm et al., (2014), Kamran et al., (2014) and Davood et al., (2015) in carnation.

\section{References}

Abdul, W. and Asrar, A. 2012. Effect of some preservative solutions on vase life and keeping quality of snapdragon (Antirrinum majus L.) cut flowers. Journal of the Saudi Society of Agricultural Sciences.11:29-35.

Davood, H., Behzad, K., Ali, S. and Dina, Y. 2015. Response of cut Carnation (Dianthus caryophyllus L. cv. Tempo) to essential oils and antimicrobial compounds. International Journal of Biosciences. 6(3): 36-44.

Edrisi, B., Sadrpoor, A. and Saffari, V. R. 2012. Effects of chemicals on vase life of cut Carnation (Dianthus caryophyllus L. 'Delphi') and microorganism's population in solution. Journal of Ornamental and Horticultural Plants. 2(1): 1-11.

Elham, H., Vali, R., Amrollah, N. and Javad, F. 2014. Postharvest quality improvement of carnation (Dianthus caryophyllus L.) cut flowers by Gibberilic Acid, Benzyl Adenine and Nano Silver. Agricultural Communications. 2(2): 28-34.

Genkov, T., Tsoneva, P. and Ivanova, I. 1997. Effect of cytokinins on photosynthetic pigments and chlorophyllase activity in in vitro cultures of axillary buds of (Dianthus caryophyllus L.). Journal of 
Plant Growth Regulation. 16(3): 169172.

Halevy, A.H. and Mayak, S. 1981. Senescence and postharvest physiology of cut flowers. Part I. In: Horticultural Reviews. Vol 2, AVI Publishing Westport, conn. 59-143.

Jeevitha. S. 2016. Effect of Holding Solution on the Vase Life of Bird-of-Paradise Cut Flower. Environment \& Ecology. 34(2): 735-739.

Kamran, A., Vahid, A., Elham, S. M. and Aida, A. 2014. Evaluation the effect of sucrose and $\mathrm{GA}_{3}$ treatment on vase life carnation cut flower (Dianthus caryophyllus var Yellow). Pelagia research library. Advances in Applied Science Research. 5(4):150-154.

Loubaud, M. and Van Doorn, W. G. 2004. Wound induced and bacteria induced xylem blockage in roses, Astilbe and Viburnum. Post-harvest Biology and Technology. 32: 281-88.

Madhuri, M., Bindu, P. R., Hari, P. R. N. and vijay, I. 2016 b. Effect of biocides on the fresh weight, chlorophyll content and microbial load in cut carnation flowers cv. Charmant. Plant Archives. 16(2), pp. 777-780.

Mohan, K. P., Nagaraju, R., Swarajya, L. K., Srinivasa reddy, D., Gopal, K. and reddy, M.L.N. 2016. Effect of different vase solutions on vase life of cut flowers cultivar Taj Mahal. International Journal of Tropical Agriculture. 34(6): 0254-8755.

Pun, U. K., Rowe, R., Rowarth, J. S., Barnes, M. F., Dawson, C. O. and Heyes, J. A. 1999. Short communication Influence of ethanol on climacteric senescence in five cultivars of carnation. N.Z.J. Crop Horticultural Science. 21: 69-77.

Singh, A., Dhaduk, B. K. and Desai, J. R. 2007. Postharvest technology and value addition in cut flowers. Floriculture today, September. pp. 40-52.

Tarannum, H. N., Narendra, S. B. And Zaheer, A. B. 2016. Effect of chemical preservations at different concentrations on vase life of carnation (Dianthus caryophyllus L.) cut flower cv. Soto. Environment \& ecology. 34(3): 981984.

Vijayabhaskar, W. 2002. Effects of chemicals and packaging material on physiological and biochemical changes during flower petal senescence and on vase life of cut rose cv. First Red. Ph.D. Thesis submitted to Acharya $N$ G Ranga Agricultural University, Hyderabad.

\section{How to cite this article:}

Pranuthi, P., T. Suseela, D.V. Swami, D.R. Salomi Suneetha and Sudha Vani, V. 2018. Effect of Holding Solutions on Biochemical and Microbial Observations in Extending the Vase Life of Cut Carnation cv. Kiro. Int.J.Curr.Microbiol.App.Sci. 7(08): 1365-1370.

doi: https://doi.org/10.20546/ijcmas.2018.708.155 